Monika Szafrańska, Renata Matysik-Pejas

\title{
1.5 FINANCIAL LITERACY IN SME BUSINESS ACTIVITY IN POLAND
}

\begin{abstract}
Summary: Globalisation, dynamic development of financial markets and modern financial products caused that SME firms have at their disposal a wide array of financial instruments. New financial services create wider possibilities but at the same time lead to a necessity of upgrading financial knowledge of SME owners or staff responsible for financial management of the enterprise.

The article aims at determining financial literacy of the persons responsible for the realization of financial policy in firms of the SME sector, but also an identification of factors determining and diversifying this level. The main source of data used for the analysis and inference was information elicited through the Author's own investigations conducted in 2011 on a group of 150 enterprises from the SME sector. Summary statistical measures and nonparametric $\left(\chi^{2}\right)$ test were used to realize the work objection.

As results from conducted investigations, the level of knowledge and financial skills of SME employees depends on the gender, age and education but also on the period of employment/conducting economic activity. Men, aged under 34 years of age, possessing higher education and employees with the longest employment period revealed a higher level of financial literacy. It has been noticed that firms managed by persons revealing a higher level of financial literacy more often use the innovative financial services, e.g. leasing or factoring.
\end{abstract}

Keywords: financial knowledge, SME, financial services

\section{INTRODUCTION}

Activities of small and medium-sized enterprises (SME) play a crucial role in economic development of each country. 1.6M of entities in SME sector are operating in Poland. These enterprises are characterized by an elasticity and easiness to adjust to market economy and response to market needs. Firms from the SME sector provide jobs for $6.5 \mathrm{M}$ people, whereas 7 out of ten working persons are employed in this sector. Considering the number of operating enterprises, Poland occupies sixth position in the European Union (PARP 2011).

Development and strengthening the market position of firms from SME sector is to a great extent possible owing to their use of a wide range of financial services, which makes possible ongoing realization of transactions, increasing investment outlays, better cash management or solving temporary problems with insolvency. A dynamic development of financial markets, modern financial products caused that SME sector has at its disposal a wide variety of financial services. On the one hand, new services create better opportunities, but on the other they make necessary upgrading financial knowledge of the owners or employees responsible for the economic management of the firm.

The objective of the article is to determine financial literacy of persons responsible for the realization of financial policy in the firms of SME sector and identification of the factors determining and diversifying this level.

\section{MATERIAL AND METHODS}

The main source of data used for the analysis and inference was primary information from the Author's own research. A directed interview technique with the use of interview questionnaire was used for the investigations. The studies were conducted in 2011 on a group of 150 entities from the sector of micro, small and medium sized enterprises operating in the 
malopolskie region. A vast majority (63\%) in the group of the analyzed entities were firms run by natural persons. Every fifth firm is a limited liability company (Ltd). The other enterprises are general or civil law partnerships. Almost $60 \%$ of the studied entities have been operating on the market for over 10 years, whereas the other have been present on the market for 5 years $(23 \%)$ or have been functioning for between 5 and 10 years $(20 \%)$. In view of employee number, dominant were micro enterprises with average yearly employment under 9 persons.

The interview was conducted with the person who makes financial decisions in the firm (owner/accountant/manager). Almost $51 \%$ of the businesses were run by women and slightly over $49 \%$ were managed by men. Firms managed by persons under 34 years of age $(40 \%)$ dominated, whereas the least number of studied enterprises $(18 \%$ of the entities) were managed by persons over 55 years of age. Every second interviewed person had secondary education and every third a higher education.

Statistical analysis of the studied material comprised:

- structure indicators,

- measures of central tendency,

- chi-square $\left(\chi^{2}\right)$ test of independence allowing to assess the significance of association between variables when at least one of them in non measurable.

Formula 1: Value of $\left(\chi^{2}\right)$

$$
\chi^{2}=\sum_{i=1}^{r} \sum_{j=1}^{k} \frac{(O i j-E i j)^{2}}{E i j}
$$

Oij - result of measurement in the $\mathrm{i}$-th line and the $\mathrm{j}$-th column

Eij - expected value in the $\mathrm{i}$-th line of the $\mathrm{j}$-th column

$d f$ - degrees of freedom

Testing of all zero hypotheses was conducted at significance level $\alpha=0.05$. In case when the number of observations in contingency table cells was lower than 8 , no testing procedure was conducted (Kaczmarczyk, 1997).

\section{IMPORTANCE OF SMES IN THE ECONOMY}

The sector of micro, small and medium sized enterprises plays a significant role in the national economy. The firms counted to this sector are often called the driving force of the economy. These entities constitute a dominating part of the total number of enterprises in market economies of many countries, including Poland. Even though they operate within a small range and have little influence on the environment in which they function, their large number makes the sector crucial for shaping the economy. Businesses, which belong to this sector, have also a considerable share in GDP creating, exports volume and generating new jobs thus counteracting the unemployment (Ganbold 2008).

SME sector fulfils a number of most important economic functions, among others comprising:

- participation in the process of changes in the country industrial structure,

- absorbing and management of considerable labour force resources,

- creating economic infrastructure necessary for efficient functioning of the system,

- playing important role in forming private ownership of factors of production,

- enforcing changes in legal regulations favouring development of entrepreneurship and better effectiveness in functioning of micro and smaller firms (Piasecki 1999). 
Sector of micro, small and medium-sized enterprises reveals a dynamic attitude towards the environment and changeable market conditions. Businesses from this sector are characterized by mobility and flexibility, which makes possible their fast reaction to arising needs and customer preferences. They are able for making fast changes in their economic operation profile, are mobile in engaging financial means in different branches and profitable investment endeavours. Businesses from SME sector may create new value for potential purchasers by devoting the necessary time and effort, but at the same time taking into consideration certain level of financial and operational risk. They base on using market opportunities but not on economy of scale. They can easily enter so called market niches, in which they can operate freely, unthreatened by the competition of large firms. Sometimes large enterprises consciously give up their activities on small markets, because for them they are unprofitable. This is an advantageous situation for micro, small and medium-sized enterprises which get involved in niche marketing and advance a more efficient functioning of the whole economy. Businesses from the SMS sector possessing adequate knowledge about the state of the market and state of the competition, immediately adjust to consumer tastes (Bartkowiak, Flejterski, Pluskota 2006).

Frequently firms from this sector become involved in activation of regional and local development through developing of new initiatives. In well-formed market economy this sector fulfils a function complementary to large firms and public sector. It is also a cooperative background supporting the functioning of large corporations.

According to Strużycki (2004) small and medium sized enterprises may gain advantage over big entities, particularly in the situation of:

- quick response to changing environment,

- openness to using innovation which may be more easily verified by market needs,

- easy entering in cooperative arrangements by fast organization of workplaces,

- entrepreneurial use of various chances and market opportunities,

- fast information flows mainly to satisfy definite needs reported by the local market,

- better competitiveness, possible to achieve through a strict control and reduction of costs.

Small and medium-sized businesses played a crucial role in the transformation processes of Polish economy. Quantitative development of these firms helped to alleviate socials stresses and reduce high costs of the transformation process. Owing to newly set up businesses from SME sector new jobs were created, which led to reduction of unemployment. They also contributed to changes in the country economy structure through developing new fields of production and new kinds of services. These businesses played also a crucial role in creating private property by taking over and managing a part of equipment previously in possession of privatized large state owned enterprises (Skowronek-Mielczarek 2007).

Three phases may be distinguished in the development of small and medium-sized enterprises in Poland. The first phase of the diagram, called initial development of entrepreneurship, had pace still during the centrally planned economy period following the introduction of legal regulations favourable for entrepreneurship. The second stage was explosion of entrepreneurship, which as indicated by the name was characterized by a dynamic development of SME sector. A fast development of entities in this sector and in consequence also employment mainly in trade, construction business and industry was registered in 1989-1994. Demand for commodities and services still unsatisfied at that time determined the trends for SMS development. Such dynamic growth of the number of economic entities resulted from two processes, foundation privatisation and state enterprises privatisation. The next phase was market self-regulation, characterized by a stabilized growth rate of businesses number before 1995. At this stage the number of entities was still growing, but not at such a high rate as in phase two (PARP 2009). 
The importance of SME sector in contemporary economic world has been evidenced by the experiences of highly developed countries. They show that economic level of a country is determined by its economy structure dominated by the network of micro, small and medium sized businesses. Just these firms reveal the biggest dynamics in taking up risks and changes, which are features indispensable in today world economy.

\section{SME SECTOR IN POLAND}

Currently micro, small and medium sized enterprises constitute $99.8 \%$ of the total number of firms in Poland and fulfil an important function in the economy influencing such crucial aspects as: economic growth, competitiveness, changes in economic structure or unemployment rate. Identical situation as regards the numbers of enterprises is in the EU, where also a vast majority of operating entities are businesses from SME sector (99.8\%). However, in Poland SME sector is to a greater extent dominated by micro firms than in the European Union (Figure 1). Their share (96\%) in the total number of enterprises outnumbers the European average (91.8\%). The share of small enterprises in the number of SME in Poland $(2.8 \%)$ is over a half lower than the mean for EU (6.9\%). Medium-term trends show that the number of micro firms is decreasing gradually, whereas the share of the other groups of entities increases.

Figure 1: Structure of active firms from the SME sector in Poland and in the EU-27

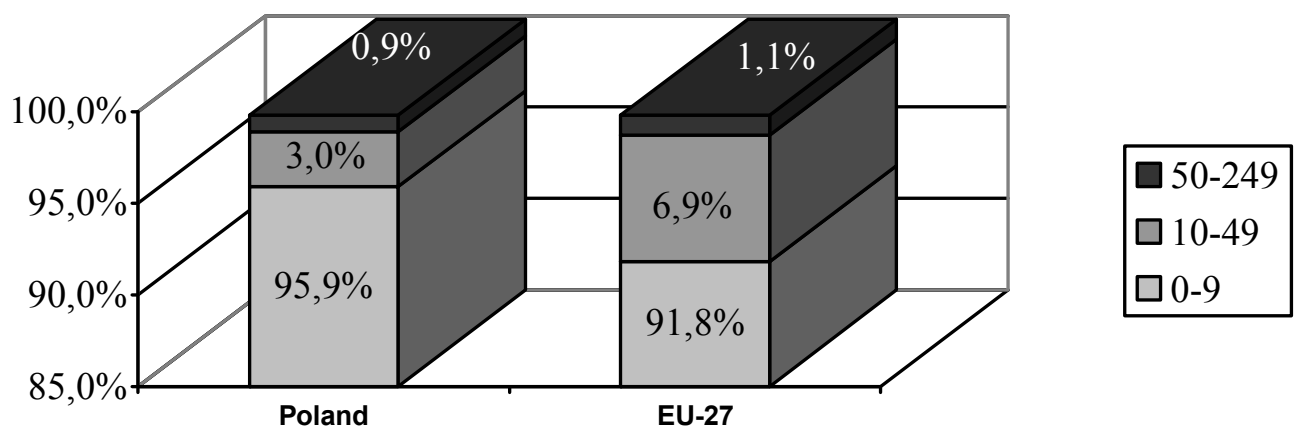

Source: GUS 2010

On the other hand, branch structure of the enterprises is slightly different than in the EU27 countries. In comparison with an average of the EU countries, Poland is characterized by a larger number of trading businesses. As results from Figure 2, almost $40 \%$ of SME operate in trading, whereas almost $36 \%$ in services.

Figure 2: SME structure in Poland and in the EU-27 according to the basic area of activity



Source: GUS 2010

\begin{tabular}{|l|}
\hline Industry \\
$\square$ Construction services \\
$\square$ Services \\
$\square$ Trade \\
\hline
\end{tabular}


The same structure in the EU shows respectively $30.6 \%$ trading and almost $45 \%$ services. In Poland, every seventh enterprise offers construction services and every tenth operates in industry. Presented data confirm a relatively lower level of Polish economy development in comparison with economies of highly developed countries. However, it should be emphasized that slowly occurring changes make the branch structure of Polish businesses similar to the structure of enterprises in the EU.

According to the Central Statistical Office data, enterprises from the SME sector operating in Poland generate almost a half of Polish GDP (48.4\%), whereas the smallest firms almost one third $(30.4 \%)$. The share of medium sized entities is thrice smaller $(10.1 \%)$ than micro firms, while the share of small ones, almost four times lower (7.9\%). The Eurostat data point to significantly lower than in the EU level of development of small businesses measured by this sector share in gross value added generated in enterprises. In Poland, the sector generates $11.5 \%$ of gross added value of enterprises, whereas in the EU-27 this share is $18.9 \%$. A noticeably bigger share in creating gross value added in Poland than in the EU-27 characterises medium sized and big entities (Figure 3).

Figure 3: Structure of generating gross value added in enterprises sector according to size of businesses in Poland and in the EU-27

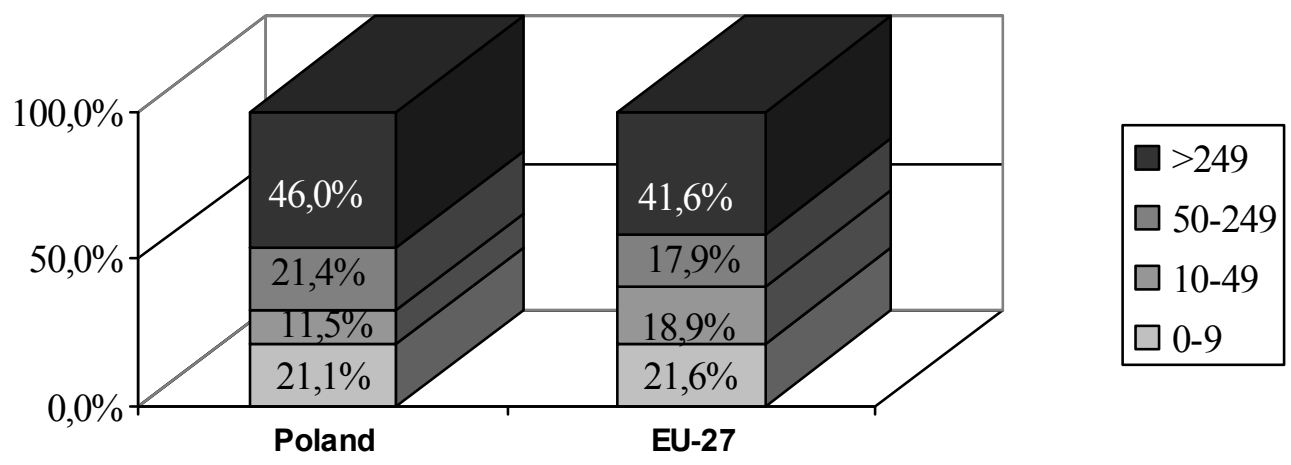

Source: GUS 2010

The proportion of persons working in SME sector in the total number of persons working in enterprises in Poland slightly exceeds $70 \%$ and is by $9.2 \%$ higher than the average for the EU-27 (Figure 4). Almost 40\% of the employed are working in microfirms (EU-30\%). The share of small businesses in the employed person's structure is $11.6 \%$. On the other hand, medium sized businesses gave a job to every fifth employed person.

Figure 4: Structure of the number of people working in enterprises in Poland and in the EU-27



Source: GUS 2010 
General picture of SME activities financing may be assessed why analysing the ways of investment outlays financing. As results from Figure 5, two thirds of SME investment outlays are financed from their own means $(64.8 \%)$.

Figure 5: Sources of financing investment outlays in 2009 in SME sector in Poland



Source: GUS 2010

The bigger the enterprises, the greater engagement of their own means in investment financing (small businesses - 61.7\%; medium-66.3\% and large $-70.1 \%$ ), determined by the economic potential. Bank credit is the most popular among the outer sources of financing (18.5\%). Medium businesses use budgetary means to the highest degree $(3.5 \%)$, which evidences that public assistance for business development inadequately takes into account the specific character of small firms. It should be emphasized that the structure of SME financing is gradually undergoing transformations. During the 2006-2009 period the importance of SMEs own means in financing investments was growing slightly (growth of the share of this source of financing from $63.4 \%$ to $64.8 \%$ ), the same applied to budgetary means (increase from $1.9 \%$ to $3.3 \%$ ) and foreign means (from $7.5 \%$ to $8.2 \%$ ), whereas the proportion of credits and national loans decreased from $21.8 \%$ to $18.5 \%$.

\section{FINANCIAL LITERACY AND EDUCATION}

Crisis on world financial markets made many people aware that lack of knowledge about rules governing the financial world may prove most harmful. It applies both to households and to enterprises operating on the market. Research conducted so far revealed that the level of financial awareness of the communities remains inadequate. As results from the studies conducted by ING group in 2010 on a sample of 10 countries (including five European ones), almost $2 / 3$ of the investigated population possessed only basic knowledge about finances. Persons from Asian countries revealed the highest level of financial awareness. A comparison of collective results was presented in Table 1.

In the literature of the subject, financial literacy is defined as an ability to analyse, manage and communicate in the area of finances (NALA 2005). On the other hand, according to "Development of Strategy Options for SME Financial Literacy" prepared by USAID (2009) a financially literate SME owner/manager is defined as someone who knows which are the most suitable financing and financial management options for his/her business at various growth stages of their business, knows where to obtain the most suitable products and services and interacts with confidence with the suppliers of these products and services. On the other hand, in the opinion of Wołowiec (2011), financial literacy is defined as the skill to obtain and possess information and use it in practice of the enterprise finances management. 
Entrepreneurs', managers or employees' lack of comprehensive knowledge about finances diminishes not only efficiency but also safety of firm's operation on the market, therefore determining the level of knowledge and competences of persons who make financial decisions in enterprises is important.

Table 1: Level of financial awareness of societies in selected countries

\begin{tabular}{|l|c|c|c|}
\hline \multirow{2}{*}{ Specification } & \multicolumn{3}{|c|}{ Level of financial awareness } \\
\cline { 2 - 4 } & Low & Medium & High \\
\hline Belgium & $72 \%$ & $23 \%$ & $5 \%$ \\
\hline Spain & $75 \%$ & $22 \%$ & $3 \%$ \\
\hline Netherlands & $64 \%$ & $29 \%$ & $7 \%$ \\
\hline India & $61 \%$ & $26 \%$ & $13 \%$ \\
\hline Japan & $56 \%$ & $36 \%$ & $8 \%$ \\
\hline South Korea & $63 \%$ & $26 \%$ & $11 \%$ \\
\hline Mexico & $81 \%$ & $16 \%$ & $3 \%$ \\
\hline Poland & $73 \%$ & $23 \%$ & $4 \%$ \\
\hline Romania & $77 \%$ & $20 \%$ & $3 \%$ \\
\hline USA & $67 \%$ & $26 \%$ & $7 \%$ \\
\hline Total & $69 \%$ & $25 \%$ & $6 \%$ \\
\hline
\end{tabular}

Source: ING International Consumer Resourcefulness. Summary of global results (2011)

Low level of financial literacy of the owners/employees of firms from SME sector may be the cause of financial exclusion. Financial exclusion denotes a lack of access to or non using financial services by an enterprise. The term was first used by Leyshon and Thrift. According to Kempson and Whyley there are six kinds of financial exclusion (FSA 2000):

- geographical access which is connected with physical accessibility of bank agencies in certain regions (e.g. more difficult access to financial institutions in rural areas),

- access exclusion is associated with a lack of access to financial services due to the scale of risk established by a financial institution,

- condition exclusion results from unmatching the terms and conditions for provision of services to needs of entities using financial services,

- price exclusion, which is caused by too high price for financial services (e.g. bank guarantees or insurance services),

- marketing exclusion is connected with a lack of interest in a given customer segment on the side of a financial institution,

- self-exclusion results from the fact that a part of entrepreneurs themselves resign from financial services because they are sure they will be refused the access to them.

As results from the "SMEs' Access to Finance survey 2011" (2011), in case of bank loan as much as $13 \%$ of entrepreneurs in Ireland do not apply for a loan because of a possible denial on the part of a financial institution. Average for the European Union is lower and reaches $6 \%$. On the other hand, in Poland the share of firms from SME sector who face this kind of exclusion is one of the lowest in Europe, i.e. about $3 \%$.

In recent years, a gradually increasing interest of banks in providing service for SME businesses has been observed in Poland. These entities are characterized by a lower power of capital and lesser stability than large entities; however, their undoubted advantage is in numbers. As has been mentioned before, microenterprises, small and medium sized businesses constitute over $99.8 \%$ of all enterprises in Poland. In this context, these businesses are an attractive segment for financial institutions. 
Currently the product destined for SMEs and generating the largest portion of bank incomes are credit products (c.a. $35-40 \%$ of bank incomes). Bank derives c.a. $30 \%$ of incomes from clearing services and c.a. 25\% from deposit and investment products. The product characterized by the highest profitability for banks and the lowest risk are short-term credits (below one year). High potential of short-term credit sales is connected with increased demand of enterprises for working capital for their economic activity. Moreover, it results from limiting long-term financing by banks. In the opinion of banks, in subsequent years the importance of clearing services will increase. Banks will focus on increasing their incomes connected with domestic and foreign settlements (Litkiewicz 2009).

One of the most efficient ways of improving financial literacy of business owners/employees are various activities in the area of financial education. According to Wołowiec (2011), financial education in a firm are wide ranging activities aimed at implementation of knowledge but also positive habits among employees leading to making proper decisions concerning finance management in compliance with current and future needs of the firm.

The basic instrument of strengthening financial literacy is a process of continuing training and education of employees. Employees' financial literacy in many businesses of SME sector is upgraded owing to the courses taught by external consulting companies. Financial consulting and training focus both on the ways of raising capital and investing free cash.

In Poland, a considerable part of initiatives aiming at increasing financial awareness in entrepreneurs/small and medium sized businesses employees is also realized by financial institutions, which beside actions promoting environmental protection, culture and sport or charitable actions undertaken in the framework of corporate social responsibility, also make endeavours aimed at financial education of the society.

As results from research conducted by Kitala, Matuszyk and Nowak (2011), these activities are largely realized using various tools accessible on banks' websites. The examples may be credit and interest calculators, FAQ forums, on-line expert advice, knowledge platforms, courses and training via Internet, and glossaries of finance and banking terms or links to other websites where one can find information helping to upgrade the knowledge and skills in the area of basic finances.

A similar source of financial knowledge is Internet financial portals, which are also involved in activities focused on financial education. The thematic range of the portals is diversified. Three groups of financial portals have been distinguished due to the profile of educational activities recipients.

Group 1 comprises portals, which contain practical information for a potential customer on financial market. He can check which services are currently available on the market and then choose the most convenient option. These website search engines usually contain tools helpful for the user, such as tools for comparing financial products, financial calculators or glossaries of terms.

Group 2 is formed of portals, which play the role of electronic financial newspapers. Information they contain are news from the world of finances focussed usually on financial markets. Useful for entrepreneurs/managers seeking information about changes occurring in the areas of their interest.

Group 3 is composed of portals created for entrepreneurs who conduct (or plant to start soon) their own businesses. The information which may be found on these portals concerns legal regulations in specific sectors of the economy, changes which accompany them and outcomes for the businessmen. The expert advice in various areas, which can be also found here is designed for persons who posses certain level of financial literacy. 
Figure 6: Access to finance in 2011 (all SMEs \% by country)



Source: SMEs’ Access to Finance Survey 2011, Analytical Report (2011)

These initiatives are very useful and needed, but they target mainly financial entrepreneurs/managers who are willing and able to use Internet resources. Financial institutions also conduct training activities in the framework of CSR and the offered courses are adjusted to the needs and requirements of beneficiaries in this respect.

Conducted educational activities successfully contribute to increase in the level of financial inclusion phenomenon. Sarma (2008) defines financial inclusion as a process, which ensures the access to, but also free use of the financial system for all participants in the economy. Roland, Bays and Chaia (2011) define financial inclusion as enabling each citizen participation in a formal financial system. On the other hand, as suggested by Ganbold (2008), financial inclusion, or broad access to financial services is defined as an absence of price and non-price barriers in the use of financial services. Improving access, then, means improving the degree to which financial services are available to all at a fair price. Studies conducted by Ipsos MORI (SMEs' Access to Finance 2011) revealed that 15\% of enterprises from SME sector in the EU pointed that the access to financing is one of basic problems, besides finding customers, which the owner/manager faces. As results from Figure 6, Greeks $(30 \%)$ and Estonians (29\%) most frequently indicated a lack of access to financing. The average for the $\mathrm{EU}$ is $15 \%$, whereas for Poland the share is slightly lower reaching $11 \%$.

Bearing in mind a necessity to strengthen financial literacy of the owners and employees of enterprises from SME sector, one should in the first place identify the level of financial literacy.

\section{THE STATE OF FINANCIAL LITERACY OF PERSONS MAKING FINANCIAL DECISIONS IN SMES}

A measurement and assessment of financial knowledge were conducted using financial literacy index. A source of information used for its construction was a test on basic definitions and financial instruments used in a SME enterprise operations. Construction of the index was based on principles of construction of financial literacy index according to Guiso and Japelli 
with Monticione's (Calgano, Monticione 2011) correction. Correct answers to questions were added and then rescaled to the range from 0 to 100. Mean value of the financial literacy index for the studied population was 52 points, whereas the maximum result - 74 points of 100 possible. The studied persons most frequently obtained 46 points (15\%).

Figure 7: Level of respondents' financial literacy

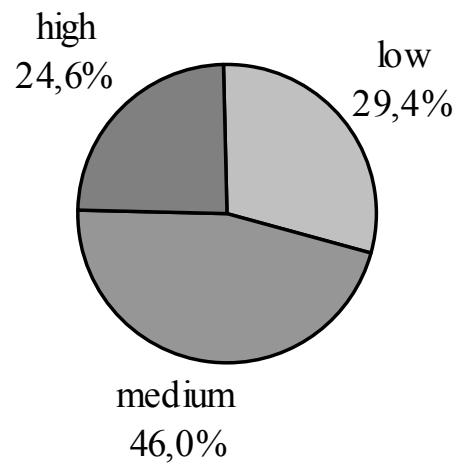

Source: Author's own studies

In order to verify the obtained results by means of $\left(\chi^{2}\right)$ test, they were grouped in three intervals: low, medium and high level of financial literacy (Figure 7). As results from the conducted analysis, $46 \%$ of persons participating in the studies revealed a medium level of financial literacy. Almost every third respondent represented low, whereas every fourth respondent a high level of knowledge on finances.

The level of financial literacy depends on respondent's gender. Men revealed a higher level of knowledge about finances. In this respondent group, every third person represented a high level of knowledge and every second a medium level. Similar results were obtained also in research conducted in Australia. Financial Literacy Score for males reached the level of 87.5, whereas the same value for females was 81.8 (ANZ Survey of Adult Financial Literacy in Australia 2008).

The factor determining the level of financial literacy is age. The share of persons in the studied population who obtained the best results of the test has been diminishing with increasing age of the respondents. The highest level of qualifications in the sphere of finances characterizes persons under 34 years of age (almost $34 \%$ of respondents reveal a high level of knowledge) and those aged between 35 and 44 years (30.3\%).

The level of competence in the area of finances depends also on education. As results from the data, every third person from the respondent group possessing vocational education reveals a low level of financial knowledge. In the group of persons possessing secondary education, only every fourth person has low qualifications in the area of finances, whereas among the best educated persons, the group makes up only about $20 \%$.

The next determinant of financial literacy is the period of running the firm (in case of owners) or employment period (employees responsible for making financial decisions). The study results indicate that with prolonging period of employment the level of entrepreneurs' or employees' financial competences rises. Every second respondent in the group of persons with the shortest employment period is characterized by a high level of financial knowledge, whereas among the entrepreneurs/employees with a long employment period, 2/3 of them possess the highest level of knowledge on finances.

Improving financial knowledge and developing positive habits among entrepreneurs or employees of small and medium-sized enterprises is facilitated by diverse measures in the framework of financial education. Despite an average level of financial literacy in the discussed respondent group, only every third investigated person is interested in upgrading his financial knowledge. These are mainly the youngest persons $\left(\chi^{2}=29.0, d f=6\right)$, equally women 
and men, respondents with higher education (44.9\%), persons characterized by the lowest and highest level of financial literacy. The need to upgrade knowledge in these two groups is probably due to other reasons. The persons who obtained a poorer result in the test are aware of a lack of knowledge necessary for running business and application of modern financial instruments. On the other hand, respondents who reveal a high level of financial knowledge feel the need for more advanced knowledge in order to use complicated financial services. Almost $40 \%$ of people were not interested in improving their knowledge, whereas every third respondent had no opinion on the matter.

Figure 8: Sources of financial knowledge preferred by respondents

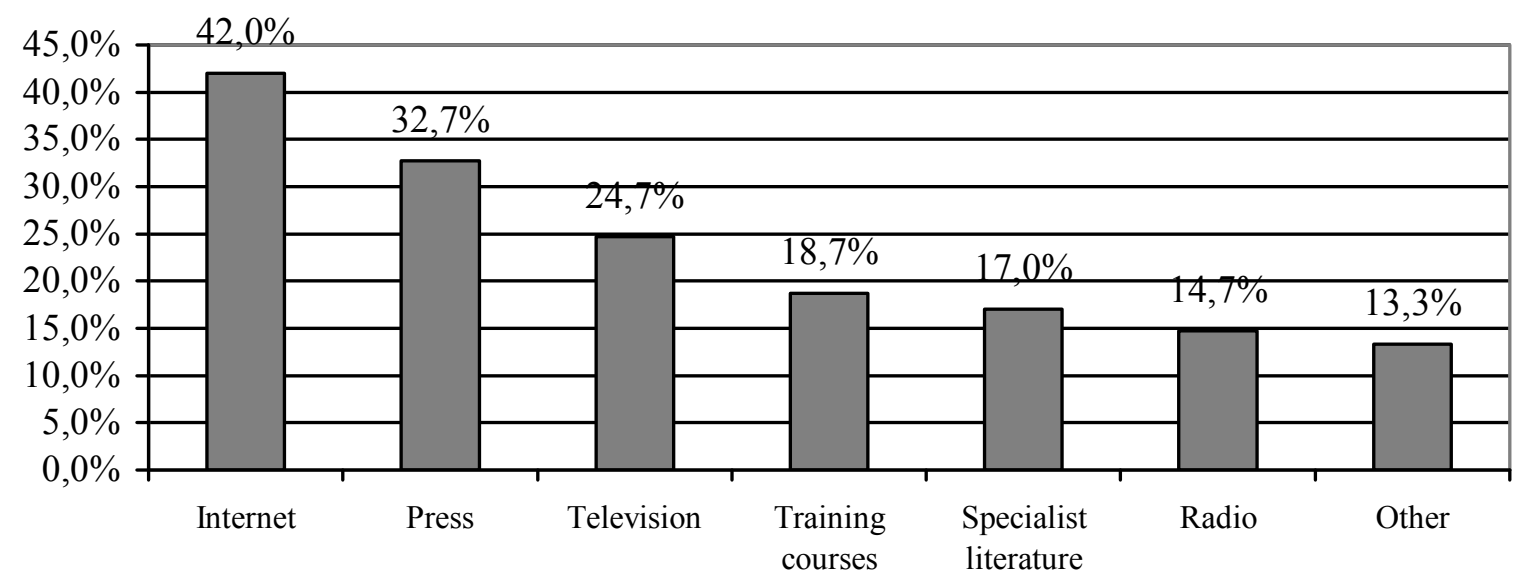

Source: Author's own studies, multiple choice, $n=150,245$ indications

Financial knowledge may be acquired from many different sources (Figure 8). Internet $(42 \%)$, press $(32.7 \%)$ and television $(24.7 \%)$ were indicated as the basic sources of financial knowledge in the group of investigated respondents. Internet was the most frequently indicated by the youngest persons $(62.7 \%$ of respondents under 34 years of age), persons with secondary and higher education (47.4\% of the above-mentioned groups, $\left(\chi^{2}=18.3, d f=3\right)$, equally females and males. On the other hand, press was the most important for males, the youngest persons and investigated persons with secondary education. Television was most frequently chosen by persons aged between 45-54, respondents possessing secondary education and men $\left(\chi^{2}=9.8, d f=1\right)$. High importance of television as a source of acquisition of financial knowledge results from its universal access. An important way to acquire financial knowledge was also participation in special courses/trainings (almost $19 \%$ of indications). Approximately $17 \%$ of the respondents marked specialist literature and $15 \%$ radio.

Skilfully applied financial knowledge allows to choose appropriate financial instruments. As results from conducted analysis the level of financial literacy of a firm owner determines its financial activity on the market (measured by the number of financial instruments which the enterprise uses). It was noticed that the higher level of competences in the sphere of finances presented by the entrepreneur, the more frequent the use of various financial instruments in the enterprise he manages.

Apart from a bank account, compulsory for enterprises, a key category of services for economic entities are credits, which make possible increasing the production, employment or introduction of innovations. Almost 55\% of the studied enterprises were repaying a credit/or credits in 2011. The results are convergent with the results presented in the Report "SMEs' Access to Finance" (2011) which show that on average, every second enterprise in UE were repaying a credit/credits in the analyzed period (e.g. HU - 49\%, SK - 55\%). Almost 53\% of the persons characterized by a low level of financial literacy were using credits, almost $50 \%$ 
of the studied persons, whose financial knowledge was estimated on a medium level and nearly $70 \%$ of the respondents characterized by a high level of financial literacy. The most popular form was an overdraft used by $43 \%$ of the studied enterprises (in UE - 40\%) (SMEs' Access to Finance, 2011). Results of statistical analysis indicate that the fact of setting up an overdraft does not depend on the level of enterprise owners' financial literacy $(\chi=3.1, d f=2)$.

On the other hand the investigations have demonstrated that using investment credit is conditioned by the level of financial knowledge of the person responsible for financial management in the firm $\left(\chi^{2}=6.3, d f=2\right)$. Every fourth of the investigated enterprises use investment credit. A higher inclination to take out this type of credit was noticed in the enterprises group managed by persons revealing a high level of financial literacy (almost $38 \%$ of entities). In the group of firms managed by persons characterised by a low level of qualifications, nearly $14 \%$ of the entities were repaying the investment credit.

Another banking service targeting the SME sector customers is working capital credit. Nearly $23 \%$ of the studied entities were using this financial product (Figure 9).

Figure 9: Financial instruments used in studied enterprises



Source: Author's own studies

We have also noticed in our research that persons characterized by a higher level of financial literacy more frequently, as compared with the other groups, use innovative financial instruments. These services comprise alternative sources of finance. Every third entity in the analysed enterprise group used leasing service. Leasing is a particular way of financing economic activity, enabling an enterprise to use tangible current assets without a necessity of their purchasing (Bien 2008). The conducted studies have shown that almost $40 \%$ of persons revealing the highest level of financial literacy were using leasing. For comparison, only $29 \%$ in the group with low level of knowledge.

Factoring is another alternative service accompanying credit, which involves buying of accounts receivable (Rutkowski 2003). 6\% of the respondents in the discussed group were using it in 2011. In this case, also a higher demand for factoring was observed in a group of persons characterized by a high level of financial knowledge. Nearly $11 \%$ of firms managed by persons who obtained the best result of test were using factoring, whereas in the group of persons revealing a low level of knowledge, factoring was used by slightly over $4 \%$ of entities.

In the analysed group of firms, only two were using European funds. It may evidence a poor knowledge on the discussed services and low level of practical financial skills of persons responsible for financial decision in the investigated enterprises. Firms managed by persons revealing a high level of knowledge were using the EU grants. 
A group of innovative services for SME sector comprises also e-banking, used by $2 / 3$ of the investigated enterprises. Popularity of this service results from its characteristics, such as 24-hour access to banking services, time saving and cost limiting (Korenik 2006). As results from the conducted analysis, the share of entities using this service was growing with increasing level of financial literacy of enterprises' owners. In case of persons characterized by the lower level of financial knowledge, about $55 \%$ of them were using e-banking, whereas in the group of persons representing a high share, over $70 \%$ entities were using services in the electronic environment.

Among other financial products used by the investigated enterprises, one should mention various deposits used by almost $13 \%$ of the firms. Bills of exchange $(10.7 \%)$ and bank guarantees $(8.7 \%)$ were most used as credit collateral.

\section{CONCLUSIONS}

In conditions of dynamic development of financial markets, complicated financial products and modern distribution channels, great skills of enterprise employees in the area of financial knowledge make possible active and rational use of diverse financial instruments, better planning for the future, improvement of the enterprise liquidity or mitigation of risk.

Presented investigations made possible determining the level of financial literacy of persons responsible for financial management in firms of SME sector. On the basis of obtained results it may be stated that the respondents revealed an average level of financial knowledge. Males, higher educated persons, aged under 34 feel best in the world of finance. The least prepared to use the potential offered by financial market to the enterprises in the SME sector are women, persons with vocational education and persons over 45 years of age.

Financial literacy is a crucial factor of functioning and development of enterprises in the SME sector, which in conditions of changes on financial markets requires constant upgrading and updating. Despite an average level of financial literacy and skills, only one in three respondents was interested in improving knowledge about finances.

Planned educational measures targeting beneficiaries from the SME sector should consider an appropriate selection of financial knowledge distribution channels. As results from the studies, the most efficient distribution channels will be Internet, press and television programmes. An important link is also specialist courses and trainings which should be adjusted to the needs and requirements of SMEs in this respect.

The level of financial literacy also determines enterprise activity of the financial market. In the enterprises whose owners or employees responsible for financial management were characterized by a slightly higher level of qualifications in the area of finances, diverse financial instruments were more often used. Analysis of the array of financial services used by the enterprises shows a wide popularity of e-banking. Results of the studies revealed also that SME sector is to a considerably higher degree interested in services financing its activity than in deposit services. Credit was used by almost $55 \%$ of the studied enterprises, leasing by something more than $30 \%$, whereas only $13 \%$ of the entities had deposits.

\section{REFERENCES}

1. ANZ Survey of Adult Financial Literacy in Australia (2008): www.anz.com (access: 14.04.2012)

2. Bartkowiak B., Flejterski S., Pluskota P (2006): Funds and Loan Services for Micro, Small and Medium-sized Enterprises: edition 1, Difin, Warszawa, p. 1-209 
3. Bień W. (2008): Zarządzanie finansami przedsiębiorstwa: edition 8, Difin, Warszawa, p. $1-365$

4. Calgano R., Monticione Ch. (2011): Financial Literacy and the Demand for Financial Advice, CeRP, "Working Paper", no 117, http://cerp.unito.it/index.php (access: 14.04.2012)

5. FSA (2000): In or out? Financial exclusion: a literature and research review, "Consumer Research", no 3, www.fsa.gov.uk (access: 30.06.2012)

6. Ganbold B. (2008): Improving Access to Finance for SME: International Good Experience and Lessons for Mongolia, No 438, www.ide.go.pl (access: 30.06.2012)

7. GUS (2010): Statistical Yearbook of the Republic of Poland 2010: edition 1, ZWS, Warszawa, p. 0-980

8. ING International Consumer Resourcefulness. Summary of global results (2011): www.ingfondy.cz

9. Kaczmarczyk S. (1997): Marketing research: edition 3, Polskie Wydawnictwo Ekonomiczne, Warszawa, p. 1-500

10. Kitala R., Matuszyk A., Nowak A.K. (2011): Analysis of educational initiatives undertaken by commercial entities, In: Financial education and awareness. IwaniczDrozdowska M., edition 1, Oficyna Wydawnicza SGH, Warszawa, p. 265-276

11. Korenik D. (2006): Innowacyjne usługi banku: edition 1, Wydawnictwo Naukowe PWN, Warszawa, p. 1-296

12. Litkiewicz M. (2009): How banks make money on small businesses? The Gdansk Institute for Market Economics, www.bankier.pl (access: 30.06.2012)

13. NALA (2005): Financial Literacy: Improving understanding, creating opportunity Summary, www.nala.ie (access: 30.06 .2012 )

14. PARP (2009): Raport on the State of the SME sektor in Poland in 2007-2008: edition 1, Agencja Reklamowo-Wydawnicza, Warszawa, p. 1-272

15. PARP (2011): Raport on the State of the SME sektor in Poland in 2011: edition 1, Agencja Reklamowo-Wydawnicza, Warszawa, p. 1-140

16. Piasecki B. (1999): Economics and Small Business Management: edition 2, Wydawnictwo Naukowe PWN, Warszawa-Łódź, p. 0-572

17. Roland T., Bays J., Chaia A. (2011): Global Financial Inclusion. www.mckinsey.com (access: 30.06 .2012 )

18. Rutkowski A. (2003): Financial Management: edition 2, Polskie Wydawnictwo Ekonomiczne, Warszawa, p. 1-508

19. Sarma M. (2008): Index of Financial Inclusion. Indian Council for Research on International Economic Relations, "Working Paper", no 215, p.0-26

20. Skowronek-Mielczarek A. (2007): Small and Medium Enterprises. Sources of Funding: edition 3, C.H.Beck, Warszawa, p. 0-308

21. SMEs' Access to Finance Survey 2011, Analytical Report, http://ec.europa/enterprise/policies/finance/files/2001_safe_analytical_report_en.pdf (access 20.05.2012)

22. USAID (2009): Development of strategy options for SME financial literacy. Final Report. http://pdf.usaid.gov/pdf_docs/PNADP093.pdf (access: 30.06.2012)

23. Strużycki M. (2004): Small and Medium Enterpises in the Regional Economy: edition 1, PWE, Warszawa, p. 0-270

24. Wołowiec T. (2011): Financial Education and Areas of Strengthening Financial Knowledge in Local Government Structures, In: Financial knowledge in actual activity of local governments units. Skica T., edition 1, WWSIiZ, Rzeszów, p. 121-128 